\title{
The vesicular Sainte-Sophie dykes: a chemically distinct, near-surface facies of the Grenville Dyke Swarm?
}

\author{
Michael D. Higgins, Fatim Hankard, Morgan Ganerød, and Rob Van der Voo
}

\begin{abstract}
Undeformed and unmetamorphosed diabase dykes up to $5 \mathrm{~m}$ wide occur in an area of $\sim 100 \mathrm{~km}^{2}$ about $50 \mathrm{~km}$ northwest of Montreal near the village of Sainte-Sophie. The dykes are subvertical and oriented east-west. The most common phenocryst phase is plagioclase (1-2 mm, exceptionally $10 \mathrm{~mm}$ ), followed by olivine, and in one dyke, pyroxene. Most dykes have vesicles 0.1-10 $\mathrm{mm}$ in diameter and fine-grained margins. Alteration is extensive: plagioclase is partly sericitized, olivine is serpentinized, and zeolites and carbonate are developed in the vesicles and matrix. Ar-Ar dating was challenging, but the weighted mean of two plateau ages indicates intrusion and cooling at $591.6 \pm 2.5 \mathrm{Ma}$. The overall characteristics of these dykes suggest that they may be a facies of the much larger Grenville dyke swarm to the west. However, there are distinct chemical differences that suggest they were fed from a different, generally more enriched mantle source. This zone may be related to the one that produced the alkaline Monteregian intrusions some 470 million years later in the same region. If the Sainte-Sophie dykes are part of the Grenville dyke event, then the use of chemical fingerprints to identify components of this swarm must be used with caution. Another difference between the SainteSophie and main Grenville dykes is the presence of vesicles and zeolites in the former, which suggests the dykes were emplaced close to the surface; hence, this crustal block has seen little erosion during the last 600 million years.
\end{abstract}

Résumé : Des dykes de diabase non déformés et non métamorphisés atteignant jusqu'à $5 \mathrm{~m}$ de largeur sont présents dans une région de quelque $100 \mathrm{~km}^{2}$ située à environ $50 \mathrm{~km}$ au nord-ouest de Montréal, près du village de Sainte-Sophie. Ces dykes sont subverticaux et d'orientation est-ouest. La phase phénocristique la plus abondante est le plagioclase (1-2 mm, exceptionnellement $10 \mathrm{~mm}$ ), suivi de l'olivine et, dans un dyke, du pyroxène. La plupart des dykes présentent des vésicules de 0,1-10 mm de diamètre et des bordures à grains fins. Ils présentent en outre une altération intense, le plagioclase étant partiellement séricitisé, l'olivine, serpentinisée, et des zéolites et des carbonates étant présents dans les vésicules et la matrice. La datation Ar-Ar s'est avérée difficile, mais la moyenne pondérée de deux âges plateau indiquent une intrusion et un refroidissement à 591,6 $\pm 2,5$ Ma. Les caractéristiques générales de ces dykes portent à croire qu'ils pourraient constituer un faciès du beaucoup plus grand essaim de dykes de Grenville plus à l'ouest. Des différences claires sur le plan chimique indiqueraient toutefois qu'ils proviennent d'une source mantellique distincte généralement plus enrichie, qui pourrait être reliée à la zone qui a produit les intrusions alcalines montérégiennes, il y a quelque 470 millions d'années dans la même région. Si les dykes de Sainte-Sophie découlent effectivement du même épisode que les dykes de Grenville, l'utilisation de signatures chimiques pour identifier des éléments de cet essaim nécessiterait donc une certaine prudence. Une autre différence entre les dykes de Sainte-Sophie et les dykes de l'essaim de Grenville est la présence de vésicules et de zéolites dans les premiers, qui donne à penser que ces dykes se sont mis en place près de la surface et, donc, que ce bloc crustal a subi peu d'érosion au cours des dernières 600 millions d'années. [Traduit par la Redaction]

\section{Introduction}

Diabase dyke swarms are ubiquitous on all the continents and throughout geologic time. They have proved very important in advancing our understanding of several processes, including the formation of large igneous provinces and reconstruction of supercontinents (Ernst 2014). Dyke swarms can extend over large areas, and it is important to identify all the members of a swarm. The best way is undoubtedly by high-precision dating of individual dykes, but this is expensive and time-consuming. For this reason, the chemical composition of dykes has been used to assign dykes to swarms, in combination with structural information on dyke orientation. The assumption is generally made that the magma for all dykes in a swarm comes from the same source. Hence, the composition of individual dykes can be related by simple petrological processes like fractional crystallization. Here, we present data that suggest this simple assumption may not always be correct. Hence, dykes that formed within a short period of time and with the same orientation may have been fed from several different sources.

\section{Regional geology}

The region of study lies in the Grenville Province, the youngest division of the Canadian Shield, with metamorphic and igneous ages from $\sim 1.6$ to $\sim 1.0 \mathrm{Ga}$ (Fig. 1). In this region, the Grenville Province is dominated by intrusions of the anorthosite-mangeritecharnockite-granite (AMCG) suite. These rocks host the SainteSophie dykes (SSD), but have not played a part in their emplacement. To the south, the Ottawa-Bonnechere and St. Lawrence grabens contain undeformed Paleozoic sedimentary rocks of the St. Lawrence lowlands succession.

Received 26 July 2017. Accepted 28 October 2017.

Paper handled by Associate Editor James Russell.

M.D. Higgins. Sciences Appliquées, Université du Québec à Chicoutimi, 555 Boulevard de l’Université, Chicoutimi, QC G7H 2B1, Canada. F. Hankard and R. Van der Voo. Department of Geological Sciences, University of Michigan, C.C. Little Building, Ann Arbor, MI 48109, USA. M. Ganerød. Geological Survey of Norway (NGU), Norway.

Corresponding author: Michael D. Higgins (email: mhiggins@uqac.ca).

Copyright remains with the author(s) or their institution(s). Permission for reuse (free in most cases) can be obtained from RightsLink. 


\section{Pagination not final (cite DOI) / Pagination provisoire (citer le DOI)}

Fig. 1. Grenville, Sainte-Sophie, Rideau, and Brockville dykes (Davidson et al. 2009; Halls et al. 2015). [Colour online.]

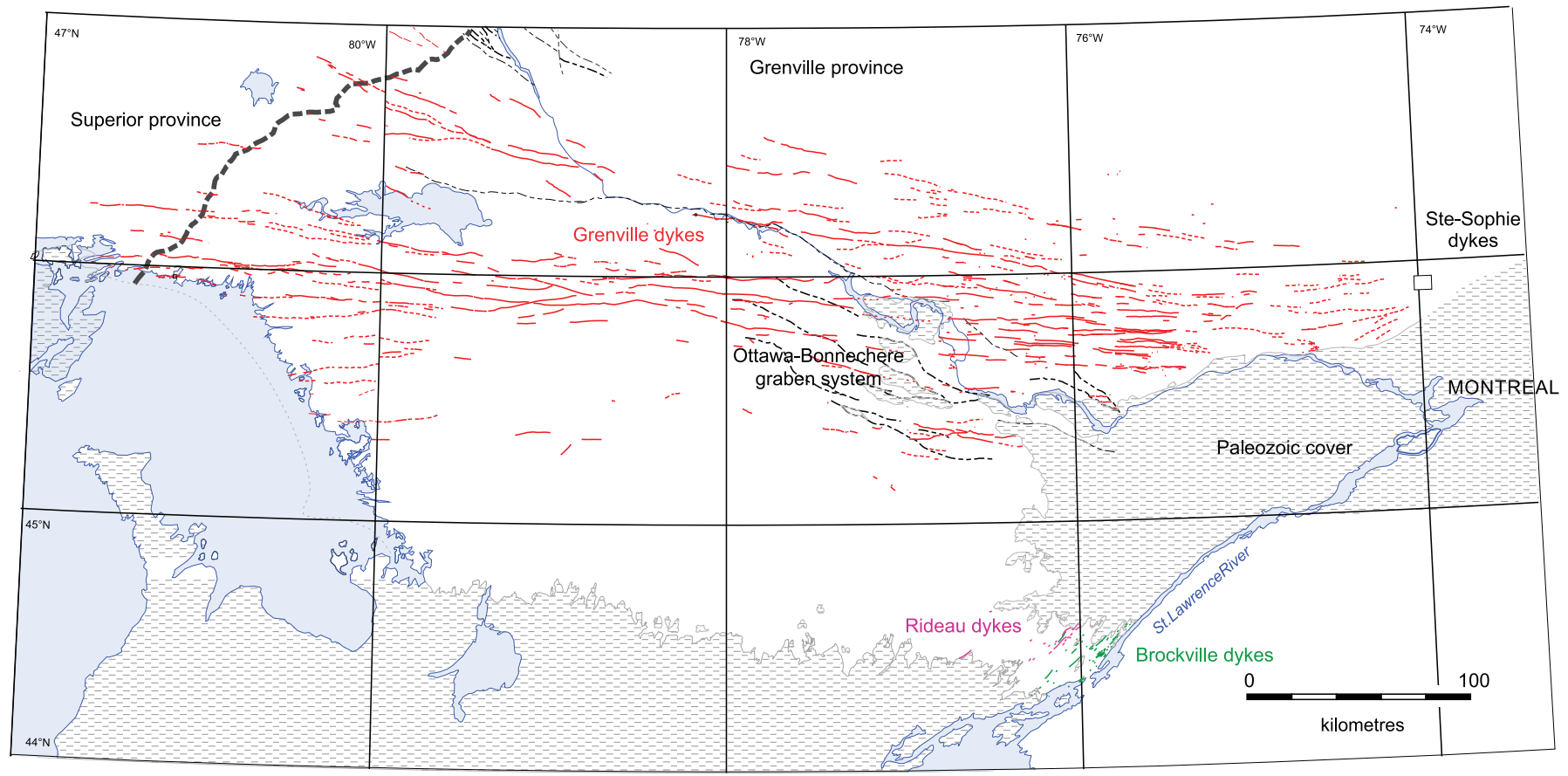

Following the Grenville Province events, there was a hiatus until about 650-600 Ma ago when magmatism associated with rifting started, a process that terminated with the opening of the Iapetus Ocean (Kumarapeli and Saull 1966). The Iapetan magmatism had three components: dyke swarms and plutons, which are now preserved in the Canadian Shield; and flood basalts, which are mostly preserved in the Appalachian fold belt (Higgins and van Breemen 1998). The most widespread Iapetan magmatic component are the Grenville dykes, which outcrop over a large area $(\sim 700 \mathrm{~km}$ by $\sim 100 \mathrm{~km})$ to the west of the Sainte-Sophie region (Davidson et al. 2009; Halls et al. 2015). The dykes generally have an east-west orientation and were emplaced $\sim 585$ Ma ago (Kamo et al. 1995; Halls et al. 2015). The chemical composition of the dykes resembles that of continental flood basalts, and has been taken to indicate derivation from a mantle plume head (Seymour and Kumarapeli 1995).

The presence of diabase dikes in the Sainte-Sophie region was first noted by Osborne and Clark in the text accompanying the geologic map of the region (Osborne and Clark 1960). However, actual dykes were not indicated on the published map, and the description was brief. They presented one analysis that suggested the dykes had a mildly alkaline affinity. They noted that the dykes did not cut the Paleozoic sedimentary rocks in the graben and hence could not be part of the Cretaceous Monteregian suite. Doig and Barton (1968) dated one dyke with the whole-rock K-Ar method and found an age of $530 \mathrm{Ma}$ (no uncertainty indicated). In general, the SSD are not well known, and it is not surprising that they do not appear in recent dyke compilations (Buchan and Ernst 2004; Ernst and Buchan 2010; Ernst 2014).

There are also other Iapetan diabase dykes to the southwest, around Kingston. The Rideau dykes have been dated at $594 \pm 5 \mathrm{Ma}$ (Davidson et al. 2009) and may be a branch of the Grenville swarm. The undated Brockville dykes are parallel to the Rideau dykes, but are petrographically contrasting, with vesicles and plagioclase macrocrysts.

\section{Sainte-Sophie dykes (SSD)}

The SSD outcrop in a small region of $10 \mathrm{~km}^{2}$, just to the northeast of Saint-Jerome, Quebec, Canada (Fig. 2; Table S1). Most dykes have been observed in road cuts and quarries, as the ubiquity of till deposits makes natural outcrops rare. We have searched for similar dykes along the roads outside this region but without success; hence, our observed limit may be the actual limit of the dykes.

Twenty-four dykes were observed in the field, mostly along roads or in quarries, and 16 were drilled for further study. The dykes are from 5 to $500 \mathrm{~cm}$ wide, with an average width of $125 \mathrm{~cm}$ (Fig. 3). Most dykes have parallel sides, but a number are irregular. Most lack internal contacts and were intruded in a single event. In some cases, one dyke cuts another. All the dykes have very finegrained contacts, and one (SS-6) has a macroscopically glassy contact about $20 \mathrm{~mm}$ wide. The strike of the SSD varies from approximately east to northeast, and most are vertical or subvertical. There is no systematic variation in orientation with location (Fig. 2). Dykes could not be traced on aeromagnetic maps, as they are too thin, and the resolution of the available magnetic data is poor.

\subsection{Petrological description}

The petrography of the SSD was explored using regular petrographic thin sections. Most of the dykes were vesicular, typically with $2 \%-5 \%$ spherical vesicles $0.1-1 \mathrm{~mm}$ in diameter. One dyke (SS-2) had vesicles to $10 \mathrm{~mm}$, and three dykes were without vesicles. All vesicles were filled with serpentine, zeolites, and (or) calcite. Plagioclase is a common phase, both in phenocrysts and in the groundmass. One dyke (SS-2) contained abundant phenocrysts (15\%) as tablets up to $12 \mathrm{~mm} \times 3 \mathrm{~mm}$. Phenocrysts were much less abundant and smaller in all other dykes. Plagioclase phenocrysts are generally relatively fresh, but are extensively sericitized in some dykes. Olivine is present in many dykes as sparse phenocrysts up to $2 \mathrm{~mm}$ long. Most are euhedral with some skeletal

${ }^{1}$ Supplementary data are available with the article through the journal Web site at http://nrcresearchpress.com/doi/suppl/10.1139/cjes-2017-0168. 
Fig. 2. The Sainte-Sophie dykes occur about $60 \mathrm{~km}$ northwest of Montreal. Basement geology after Osborne and Clark (1960). Inset: Stereonet of poles to dyke orientations. Qtz, quartz. [Colour online.]

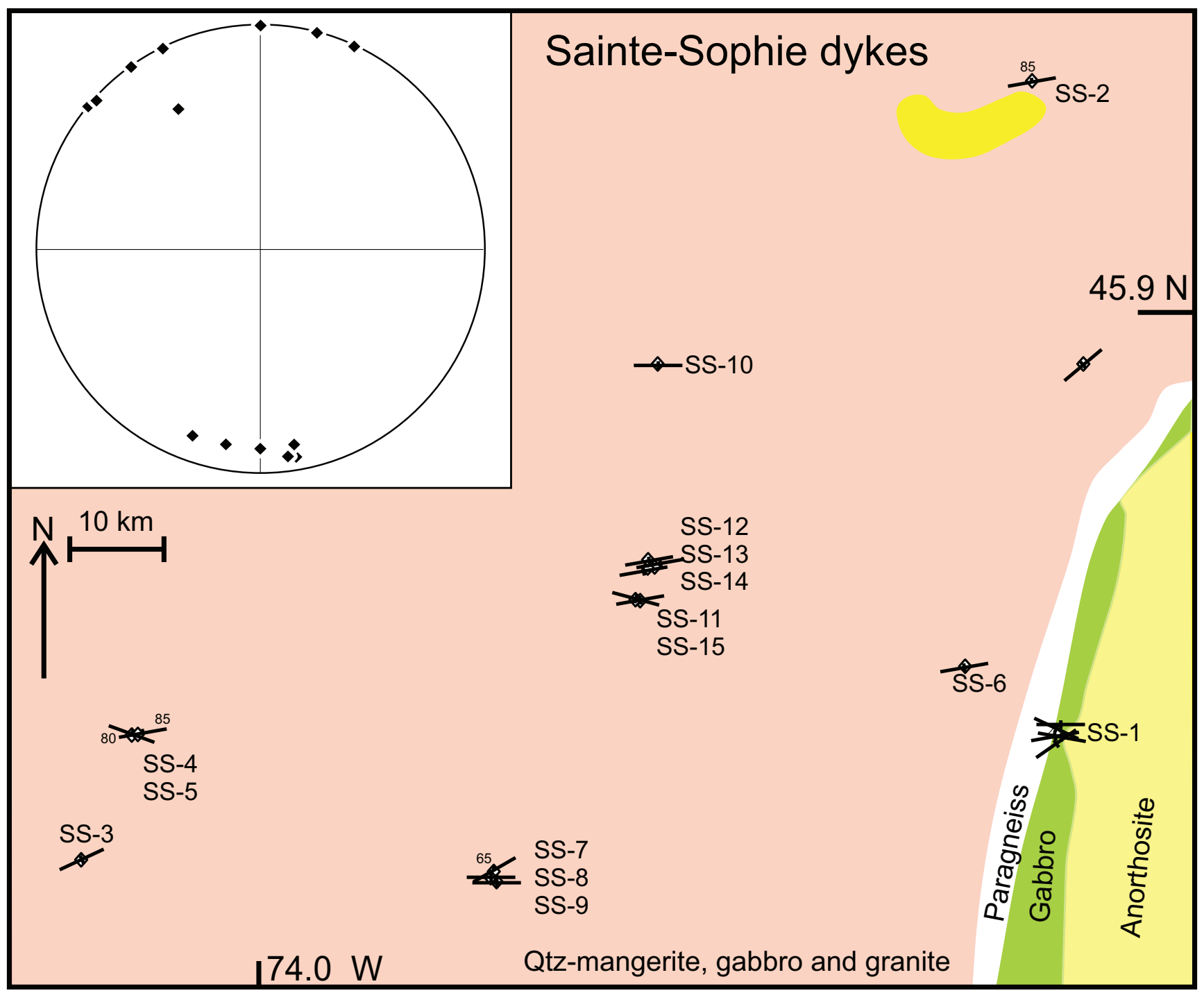

crystals. Although a few dykes have fresh olivine, it is commonly altered, sometimes completely, to serpentine, magnetite, and carbonate. One dyke contained phenocrysts of clinopyroxene to $1 \mathrm{~mm}$. The groundmass of the dykes is very variable. Plagioclase is ubiquitous, but the grain size is very variable. Olivine and clinopyroxene are common. Olivine is more commonly altered than clinopyroxene. Magnetite is abundant in the groundmass of some dykes. Serpentine, carbonate, and zeolites are present in many dykes. A few dykes have an opaque groundmass, which may be still glassy, or devitrified (Fig. 4D).

\section{Whole-rock geochemistry}

\subsection{Major elements}

The major-element composition of 14 SSD samples was determined by X-ray fluorescence (XRF) at Geolabs, Sudbury, Ontario (Table S2 ${ }^{1}$ ). Accuracy is considered to be less than $1 \%$. Samples were generally taken from the centre of the dykes. To this was added the one analysis from Osborne and Clark (1960). The widespread alteration of the samples is expressed by loss-on-ignition (LOI) values from $1.7 \%$ to $8 \%$ (Table S2 ${ }^{1}$ ). Such high values make it difficult to compare analyses of different dykes; hence, we have assumed that alteration is generally isochemical, except for the
Fig. 3. Dykes have chilled margins, some glassy, and some show textural evidence (internal chill zones) for multiple injections. [Colour online.]

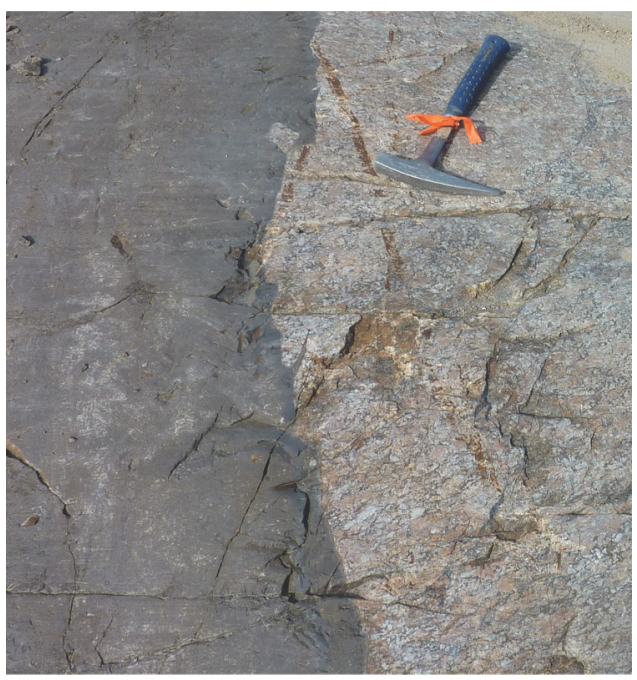


Fig. 4. Petrographic textures are quite variable. In many dykes, the margin is fine grained or even glassy (A, D), but the core is quite coarse grained (B). Most dykes are vesicular (C), and in many, the mafic minerals are altered to serpentine and carbonate. [Colour online.]
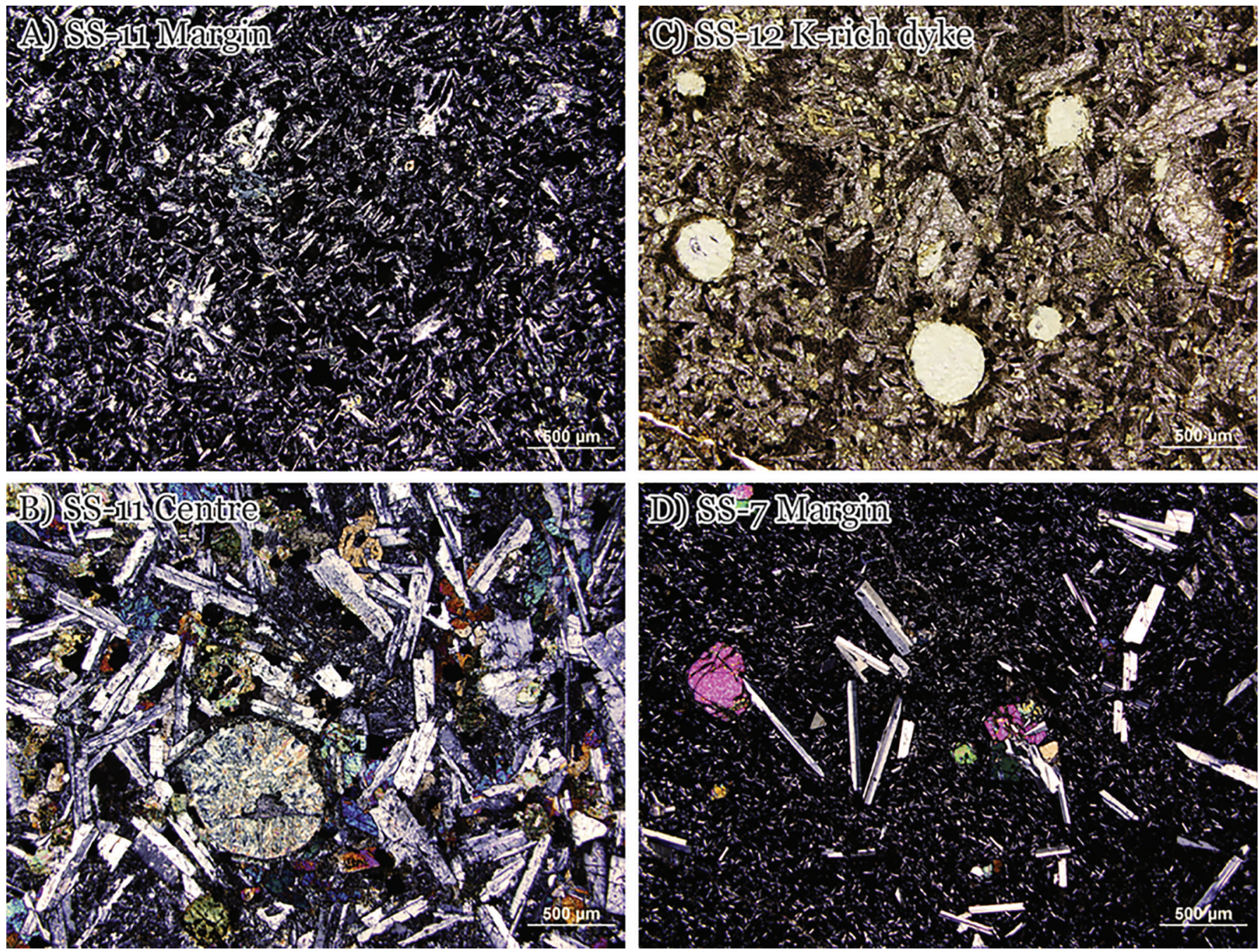

addition of volatiles, and anhydrous values have been used in the figures and discussion.

$\mathrm{SiO}_{2}$ values varied continuously from $46 \%$ to $50 \%$, but $\mathrm{K}_{2} \mathrm{O}$ concentrations are strongly bimodal (Fig. 5A): Dykes SS-12 and SS-13 have $\sim 6 \% \mathrm{~K}_{2} \mathrm{O}$, whereas all others have values of $0.3 \%-1.4 \%$. This suggests that there are two populations of dykes and that SS-12 and SS-13 should be treated separately from the other dykes. The sample from Osborne and Clark (1960) is slightly richer in $\mathrm{K}_{2} \mathrm{O}$ than the samples analyzed here, but far from the high-K samples. On a $\mathrm{Na}_{2} \mathrm{O}+\mathrm{K}_{2} \mathrm{O}$ versus silica diagram (Fig. $5 \mathrm{~B}$ ), SS-12 and SS-13 are strongly alkaline, but the others are subalkaline. Hence, the epithet "alkali dykes" used by Osborne and Clark (1960) to describe these dykes is not correct, except for the two K-rich ones. $\mathrm{MgO}$ concentrations are from $\sim 5 \%$ to $8 \%$ for most dykes, except for one of the high-K dykes, which has nearly $12 \% \mathrm{MgO}$. These concentrations translate to $\mathrm{Mg}$ numbers (atomic) of 38-64. $\mathrm{CaO}$ concentrations range from $\sim 6 \%$ to $11 \%$, except for the two K-rich samples that are exceptionally low in $\mathrm{CaO}-1.2 \%-1.3 \%$. Dyke SS-2 was petrographically distinct, with abundant plagioclase tablets to $10 \mathrm{~mm}$, but it is not compositionally distinct from the other low- $\mathrm{K}$ dykes.

\subsection{Trace elements}

The trace-element composition of 14 SSD samples was determined by closed-vessel solution and inductively coupled plasma - mass spectrometry at Geolabs, Sudbury, Ontario (Table S2 ${ }^{1}$ ). Accuracy is considered to be less than $10 \%$. The samples were the same as those used for major-element analysis, except three dykes that were sampled from both the edge and centre.

Trace-element abundances were plotted against $\mathrm{Zr}$, as it is incompatible in major minerals and is precisely determined (Fig. 6). A plot of La versus $\mathrm{Zr}$ is almost linear, as would be expected, as both elements are incompatible in mafic minerals. The linear trend also suggests that the sources of the different dykes are homogeneous with respect to $\mathrm{La} / \mathrm{Zr}$ ratios. The actual abundance of both trace elements is very variable, with a factor of four between the concentrations in the most and least enriched samples. The sample with the lowest $\mathrm{La}$ and $\mathrm{Zr}$ (SS-5) does not appear to be petrographically different from the other samples. The two K-rich samples (SS-12, SS-13) are along the same overall trend, although close to the lower La side. Two of the three centre-rim pairs are almost coincident, but the third has a significant dispersion parallel to the overall trend. $\mathrm{Rb}$ is another element incompatible in major mafic phases and is generally positively correlated with $\mathrm{Zr}$, as would be expected (Fig. 6C). However, the dispersion of the data is much greater than for La versus $\mathrm{Zr}$. The two K-rich samples stand out as having a much higher abundance of $\mathrm{Rb}$ for their $\mathrm{Zr}$ content. The overall dispersion of the other samples probably reflects source heterogeneity. $\mathrm{Sr}$ is compatible in plagioclase, 
Fig. 5. Major-element compositions of the Sainte-Sophie dykes by XRF, expressed on an anhydrous basis: $(\mathrm{A}) \mathrm{K}_{2} \mathrm{O}$ versus $\mathrm{SiO}_{2}$; $(\mathrm{B}) \mathrm{Na}_{2} \mathrm{O}+\mathrm{K}_{2} \mathrm{O}$ versus $\mathrm{SiO}_{2} ;(\mathrm{C}) \mathrm{MgO}$ versus $\mathrm{SiO}_{2}$; (D) $\mathrm{CaO}$ versus $\mathrm{SiO}_{2}$. All Sainte-Sophie dykes data are from this study, except for one analysis from Osborne and Clark (1960), indicated with a paler symbol. Grenville dyke analyses are from Seymour and Kumarapeli (1995) and Ernst and Buchan (2010). Compositions of Rideau dykes are from Ernst and Buchan (2010). [Colour online.]
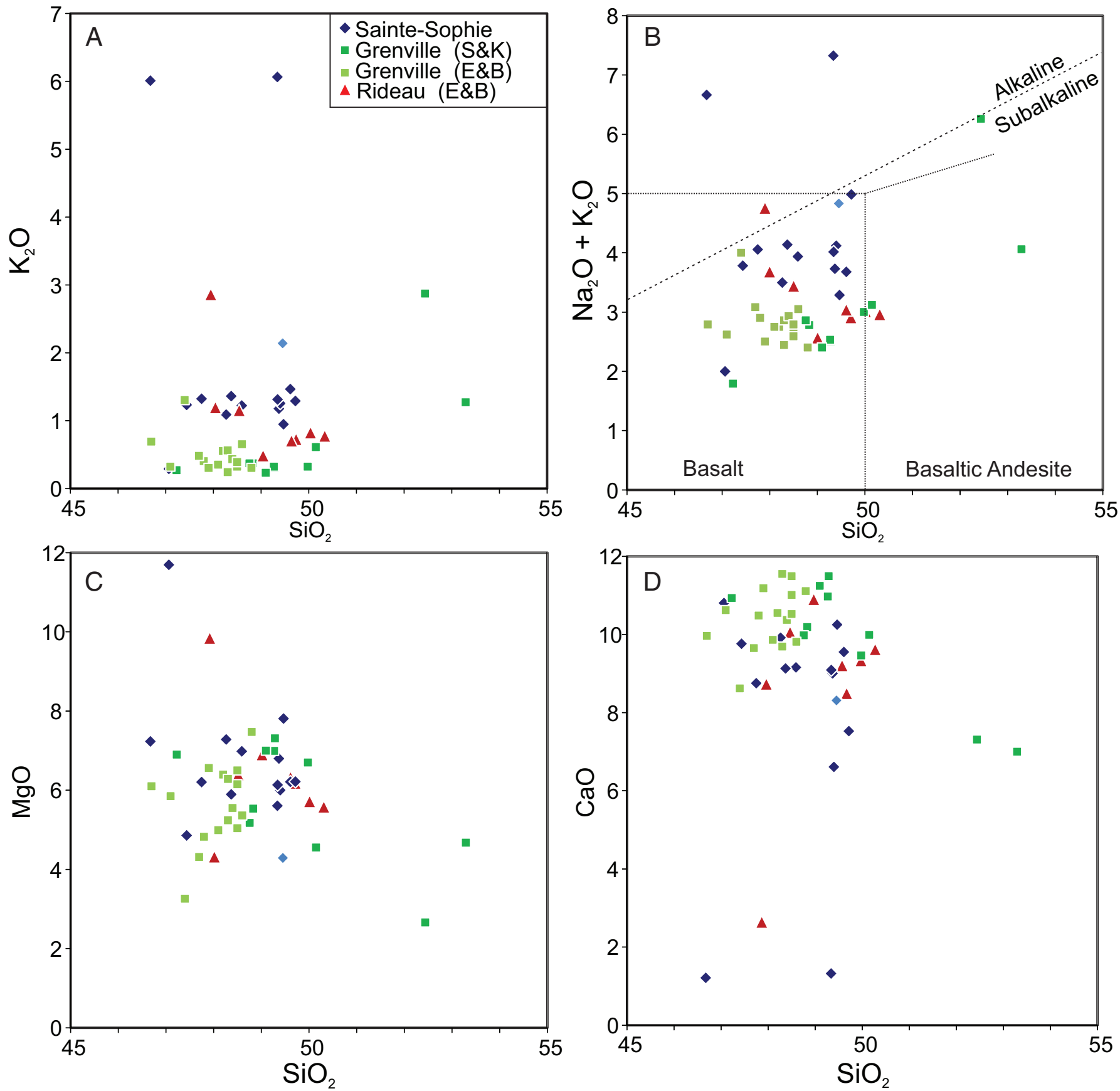

which is a phenocryst phase in the SSD. Hence, we might expect that $\mathrm{Sr}$ and $\mathrm{Zr}$ would not be correlated, but this is not the case. As for $\mathrm{La}$ and $\mathrm{Rb}, \mathrm{Sr}$ and $\mathrm{Zr}$ are broadly correlated, but with much dispersion. The two high-K samples (SS-12, SS-13) have similar but much lower Sr contents than the other ones. For SS-10, there is a considerable difference in the $\mathrm{Sr}$ content between the centre and the rim, and the compositional vector is not parallel to the overall compositional trend. A plot of $\mathrm{SiO}_{2}$ versus $\mathrm{Zr}$ is very dispersed, without any clear trend. The two high-K samples (SS-12, SS-13) do not particularly stand out from the other dykes.

Chondrite-normalized rare-earth element (REE) abundances show smooth, subparallel curves (Fig. 7A). All samples have nega-

tive Eu anomalies, with Eu/Eu* values from 0.9 to 0.7 (Fig. 7B). The high-K samples have the most significant Eu anomalies. $\mathrm{La}_{N} / \mathrm{Lu}_{\mathrm{N}}$ is relatively constant for most samples, except SS-5, which has the lowest total REE content.

\section{Geochronology}

The "gold standard" for dating of diabase dyke swarms is undoubtedly $\mathrm{U}-\mathrm{Pb}$ dating of baddeleyite and skeleton zircon. We searched extensively for baddeleyite and zircon in our samples but did not find it. This is probably because our dykes were relatively thin $(<5 \mathrm{~m})$ and did not cool sufficiently slowly for these 
Fig. 6. (A-C) Trace-element content of the Sainte-Sophie dykes. Pairs of samples from the edge and centre of the same dyke are linked with a line. (D) Comparison of major- and trace-element abundances. [Colour online.]
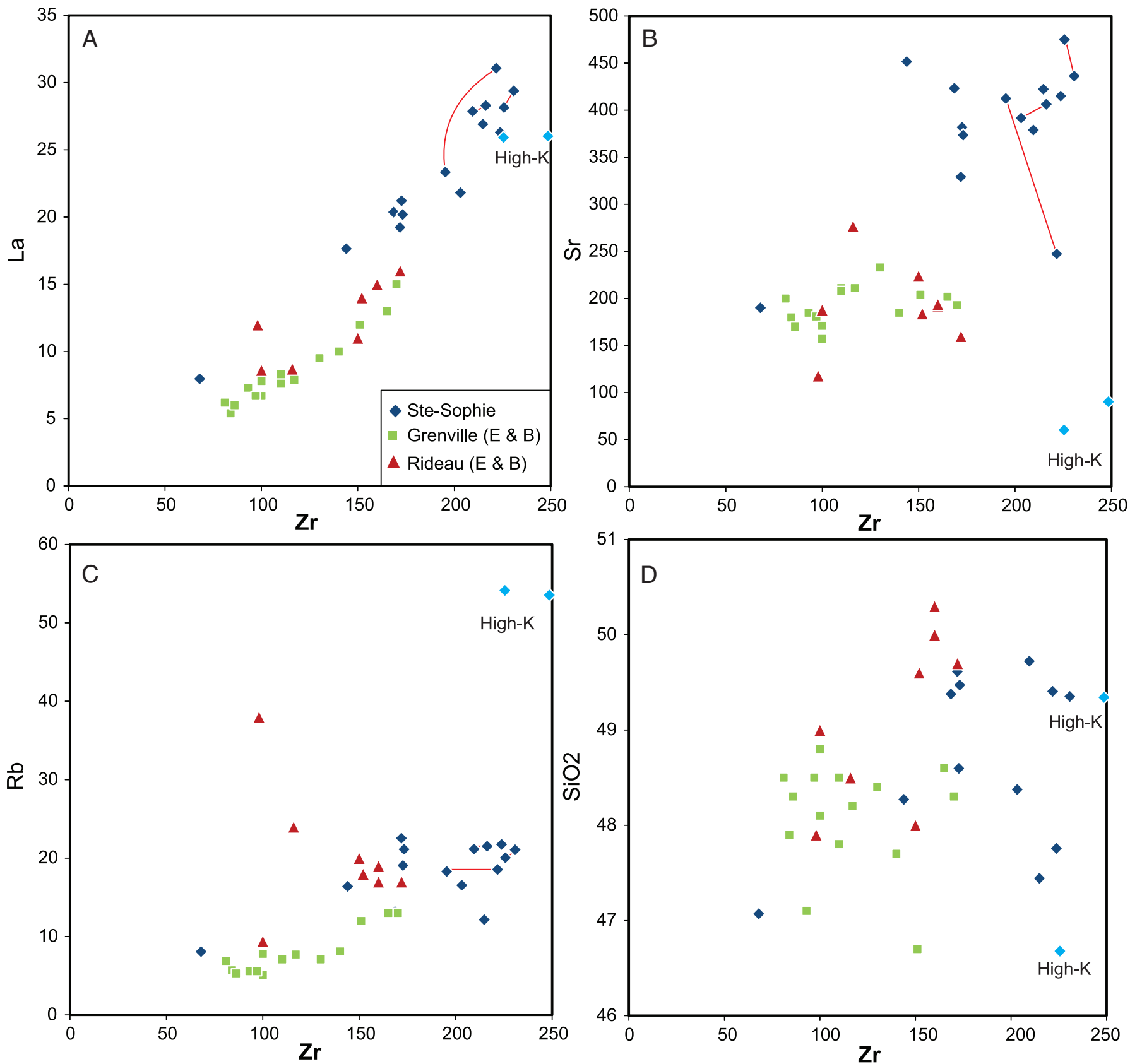

minerals to grow into crystals large enough to be recovered. We therefore attempted to date the SSD using Ar-Ar methods on mineral separates and whole rocks, despite the extensive zeolite alteration of the samples. Eight samples in total, including whole rock and plagioclase, were found suitable and were processed further for age determination.

The rock samples were crushed, ground, and subsequently sieved to obtain $180-250 \mu \mathrm{m}$ fractions. A portion was set aside for whole-rock analysis. The mineral separates were washed in acetone and deionized water several times before handpicking and finally handpicked under a stereomicroscope. Mineral grains with coatings or inclusions were avoided. The samples were packed in aluminum capsules together with the Hb3gr amphibole (batch $\mathrm{PP}-20$ ) flux monitor standard along with pure (zero age) $\mathrm{K}_{2} \mathrm{SO}_{4}$ and $\mathrm{CaF}_{2}$ salts. The samples were irradiated together at IFE (Institutt

for Energiteknikk, Kjeller, Norway) for 157 h, with a nominal neutron flux of $1.3 \times 10^{13}$ neutrons $\cdot \mathrm{cm}^{-2} \cdot \mathrm{s}^{-1}$. The correction factors for the production of isotopes from Ca were determined to be $\left({ }^{39} \mathrm{Ar} /\right.$ $\left.{ }^{37} \mathrm{Ar}\right)_{\mathrm{Ca}}=(7.907 \pm 0.0653)\left(10^{-4}\right)$ and $\left({ }^{36} \mathrm{Ar} /{ }^{37} \mathrm{Ar}\right)_{\mathrm{Ca}}=(3.1122 \pm$ $0.0473)\left(10^{-4}\right)$, and $\left({ }^{40} \mathrm{Ar} /{ }^{39} \mathrm{Ar}\right)_{\mathrm{K}}=(1.614698 \pm 0.12631)\left(10^{-2}\right)$ for the production of $\mathrm{K}$ (errors quoted at $1 \sigma$ ). The samples were step heated using a defocused Merchantek $\mathrm{CO}_{2}$ laser. The extracted gases were passed over SAES GP-50 getters for the first $2 \mathrm{~min}$, then for $9 \mathrm{~min}$ in a separate part of the extraction line with SAES AP-10 getters. They were analyzed with an automated MAP 215-50 mass spectrometer in static mode, installed at the Geological Survey of Norway. The peaks were determined during peak hopping for 10 cycles (15 integrations per cycle) on the different masses ( $\left.{ }^{41-35} \mathrm{Ar}\right)$ on a Balzers electron multiplier and regressed back to zero inlet time. Blanks were analyzed every third measurement. After blank 
Fig. 7. (A) Representative chondrite-normalized REE compositions for the Sainte-Sophie dykes and ranges of values from the Grenville, Brockville, and Rideau dykes (Davidson et al. 2009; Ernst and Buchan 2010). (B) REE slope and Eu anomalies of the Sainte-Sophie dykes. Pairs of samples from the edge and centre of the same dyke are linked with a line. [Colour online.]
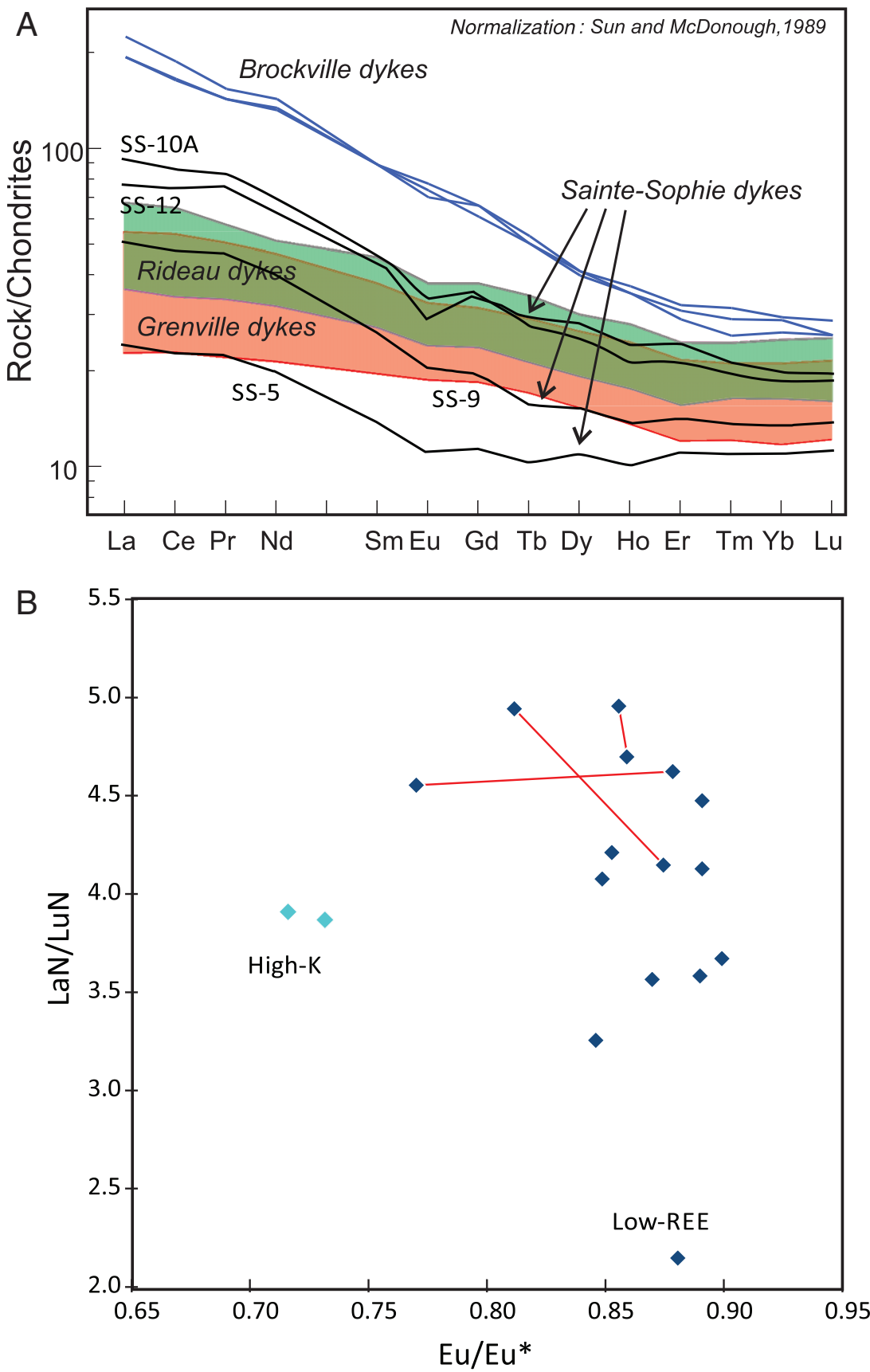

correction, a correction for mass fractionation, ${ }^{37} \mathrm{Ar}$ and ${ }^{39} \mathrm{Ar}$ decay, and neutron-induced interference reactions produced in the reactor was undertaken using in-house software (AgeMonster, written by M. Ganerød). It implements the McDougall and Harrison equations (McDougall and Harrison 1999) and the newly proposed decay constant for ${ }^{40} \mathrm{~K}$ after Renne et al. (2010). A ${ }^{40} \mathrm{Ar} /{ }^{36} \mathrm{Ar}$ ratio of $298.56 \pm 0.31$ from Lee et al. (2006) was used for the atmospheric argon correction and mass fractionation calculation (power law). We calculated $J$ values relative to an age of 1080.4 $\pm 1.1 \mathrm{Ma}$ for the Hb3gr sanidine flux monitor (Renne et al. 2010). Weighted mean ages are calculated by weighting on the inverse of the variance (analytical uncertainties).
The extensive alteration of the dykes invalidated the results from many of the dykes, but two samples proved useful. SS-2 and SS-7 had concordant steps for most of the percentage of ${ }^{39} \mathrm{Ar}$ released and resulted in weighted mean plateau ages of $591.6 \pm$ 2.5 Ma (SS-2, whole rock) and 592.4 $\pm 14.52 \mathrm{Ma}$ (SS-7, plagioclase; Fig. 8). The inverse isochrons gave similar results with a trapped contaminant argon of atmospheric composition, which validated the use of plateau ages. A similar result, dated at 587.2 $\pm 4.2 \mathrm{Ma}$, was obtained from plagioclase from sample SS-10 but consists only of $\sim 30 \%{ }^{39} \mathrm{Ar}$ released and was therefore only used as supporting evidence. The $\mathrm{K} / \mathrm{Ca}$ ratios of the two plagioclase samples indicated that they are void of any high-K alteration phase such as 
Fig. 8. Ar-Ar dating results: (a) whole-rock sample of dyke SS-2; (b) plagioclase separate from dyke SS-7. MSWD, mean square weighted deviation; $P$, probability; WMPA, weighted mean plateau age. Subscripts of argon isotopes: a, atmospheric; $\mathrm{k}$, derived from potassium; a+r, atmospheric + radiogenic. [Colour online.]

\section{a) SS2, Whole rock}
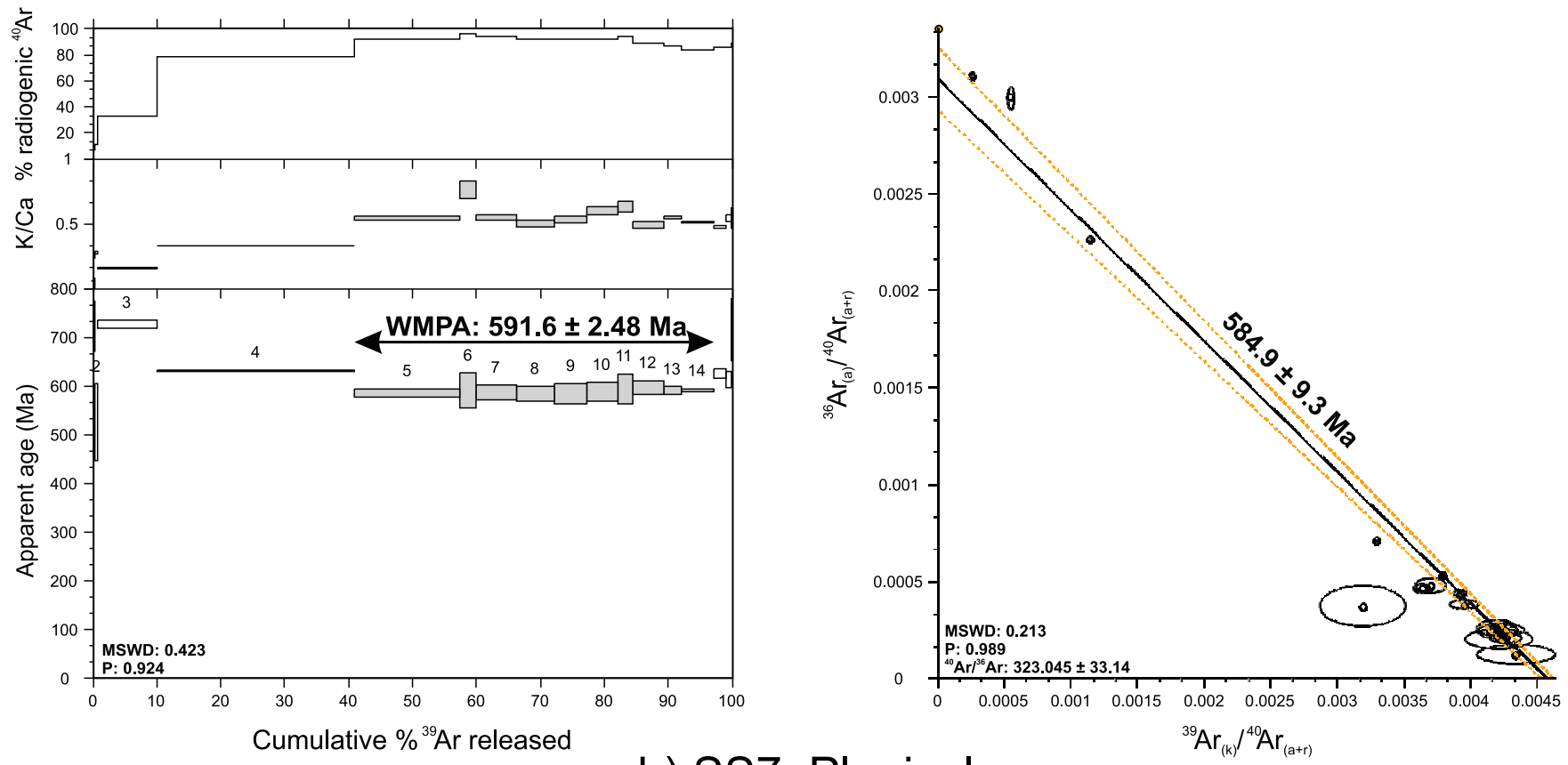

b) SS7, Plagioclase

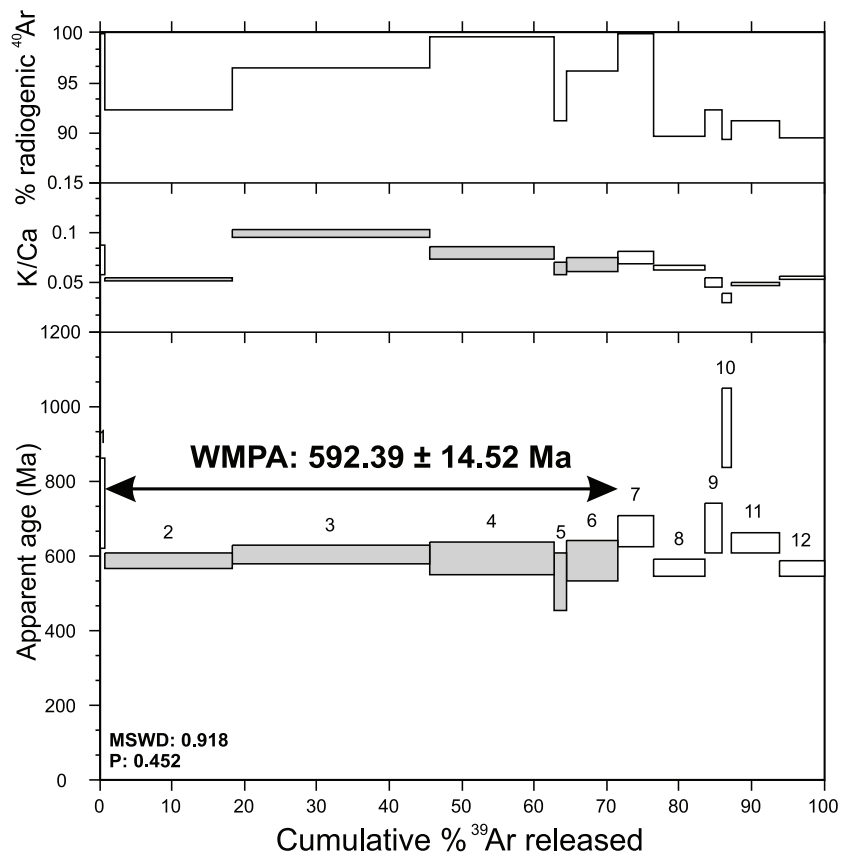

sericite, which pointed to degassing of argon from a pure plagioclase separate (Verati and Jourdan 2014). Whole-rock samples SS-6, SS-7, and SS-8 showed a clearly disturbed pattern and did not give useful information. The overall age of the dykes is considered to be $591.6 \pm 2.5 \mathrm{Ma}$.

\section{Discussion}

\subsection{Introduction}

There are many mafic dyke swarms in Canada, some of which overlap in space and time, and it is not always easy to assign

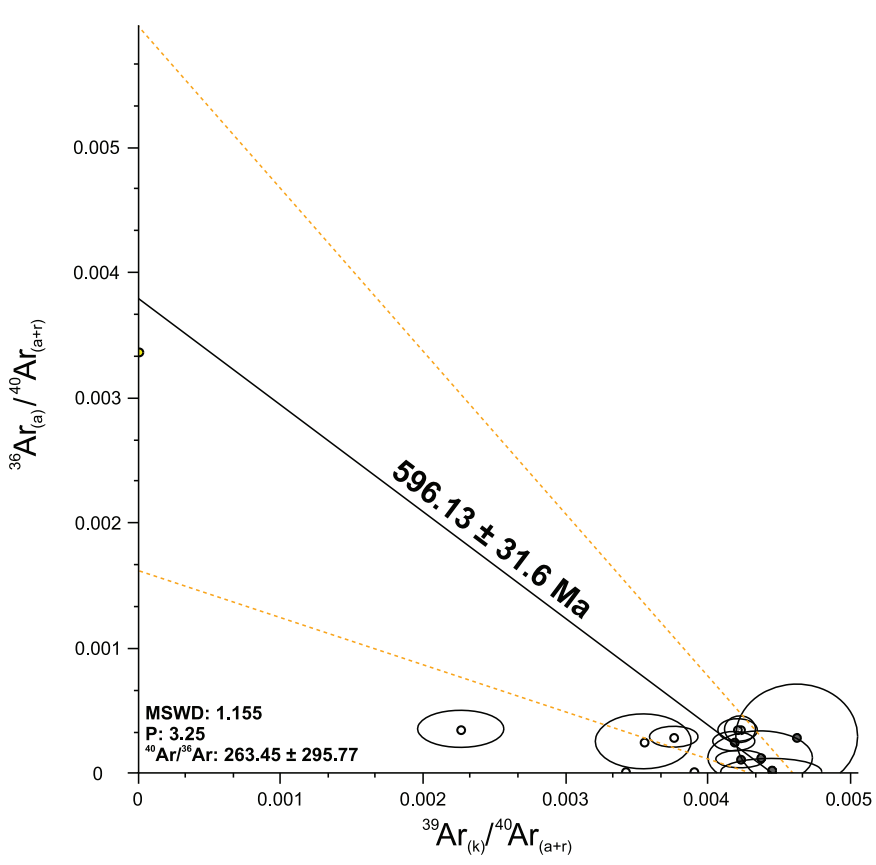

individual dykes to a particular swarm (Ernst and Buchan 2010). The most important evidence is generally considered to be dyke orientation and physical characteristics, followed by age and chemical composition. This order reflects a balance between the ease of observation and expected variability.

There are several dyke swarms west and southwest of the SSD (Fig. 1). The largest by far is the $600 \mathrm{~km}$ long Grenville dykes. The orientation of the SSD is similar to that of the Grenville dykes, and they lie on an eastward extension of the Grenville dyke swarm. However, there are significant differences in their composition 


\section{Pagination not final (cite DOI) / Pagination provisoire (citer le DOI)}

(see later) and physical characteristics, such as width and degree of alteration. The Rideau and Brockville dykes occur about $200 \mathrm{~km}$ to the southwest of the SSD. Although they cannot be confused with the SSD, they have several characteristics that make it worthwhile to include them in the discussion.

\subsection{Age of dyke-forming events}

Previous geochronological work on the SSD is limited to wholerock $\mathrm{K}$-Ar analyses of the glassy margin and coarse-grained centre of a dyke (Doig and Barton 1968). The $\mathrm{K}_{2} \mathrm{O}$ content of the samples, $1.4 \%$ and $1.8 \%$, are similar to that of the bulk of the SSD analyzed here. The location of the dyke is unknown, but only one dyke was found in this study that had a thick glassy margin (SS-6) and similar $\mathrm{K}_{2} \mathrm{O}$ content (1.13\%). This outcrop was beside an established road and could have been exposed there in the 1960s. The analyses had low atmospheric contamination (6\%-7\%) and gave similar ages of 528 and $532 \mathrm{Ma}$ (adjusted to the decay constants of Steiger and Jager 1977), but the uncertainties in the ages are not known.

Although the extensive alteration of the SSD invalidated the results from many of the samples, two samples gave acceptable $\mathrm{Ar}-\mathrm{Ar}$ ages that coincide at $592 \pm 3 \mathrm{Ma}$ (Fig. 8). Clearly, our geochronological data do not agree with the study of Doig and Barton (1968). This begs the question as to why there is such a discrepancy between the age determinations. The age found by Doig and Barton (1968) is similar to Ar-Ar ages of two intrusions found in the area, the Chatham-Grenville intrusion, $531 \mathrm{Ma}$, and the Rigaud intrusion, $533 \mathrm{Ma}$ (McCausland et al. 2007). Perhaps the SSD have two phases at $\sim 592$ and $\sim 530 \mathrm{Ma}$. If so, then the later phase was not detected in any of our data.

The Grenville dykes have been dated by a number of authors using $\mathrm{U}-\mathrm{Pb}$ on baddeleyite. The most recent and precise results give ages of 587-576 Ma (Halls et al. 2015). Earlier dates published only as abstracts give ages of 592-585 Ma (Buchan and Hamilton 2009; Buchan et al. 2011). The Rideau dykes have been dated at $590 \mathrm{Ma}$ (Davidson et al. 2009). With an age of $591.6 \pm 2.5 \mathrm{Ma}$, the SSD appear to be synchronous with the Grenville and Rideau dyke swarms, defining a widespread magmatic event. The Brockville dykes are as yet undated.

\subsection{Petrology and geochemistry of dykes}

The petrology of the SSD can be expressed in terms of their crystal texture and chemical composition. The SSD generally have plagioclase phenocrysts, unlike the aphyric Grenville and Rideau dykes. The Brockville dykes resemble the SSD with similar-sized plagioclase phenocrysts.

The major-element composition of the SSD can be compared with that of the other dyke swarms (Fig. 5; Seymour and Kumarapeli 1995; Ernst and Buchan 2010). The range of $\mathrm{SiO}_{2}$ concentrations of all three dyke swarms is generally similar, except for two Grenville dykes with much higher silica contents. $\mathrm{K}_{2} \mathrm{O}$ concentrations of the SSD are generally higher than those of the Grenville dykes, but again there are outliers with similar concentrations. The Rideau dykes cover the whole range. On a total alkali - silica diagram, the SSD have higher total alkalis than most of the Grenville dykes. The MgO content of all three dyke swarms are similar except for a single high-MgO Sainte-Sophie dyke. $\mathrm{CaO}$ concentrations give the same story except that the outliers are the high-K dykes. Trace-element composition distributions are similar to those of the major elements (Figs. 6, 7): most dykes fall into distinguishable fields, but some outliers overlap. Hence, the overall story is that most SSD can be clearly distinguished from Grenville and Rideau dykes, but there are outliers with more extreme compositions in all three dyke swarms.

The negative Eu anomalies of the SSD suggest that original mantle melts have been modified by fractionation of plagioclase. The high-K dykes appear to have had much more fractionation. The plagioclase phenocrysts in the SSD are the remains of this
Fig. 9. Whole-rock trace-element compositions of dykes from swarms in eastern Ontario and western Quebec: Grenville, Brockville, and Rideau dykes (Seymour and Kumarapeli 1995; Davidson et al. 2009; Ernst and Buchan 2010); Sainte-Sophie dykes (this study). [Colour online.]

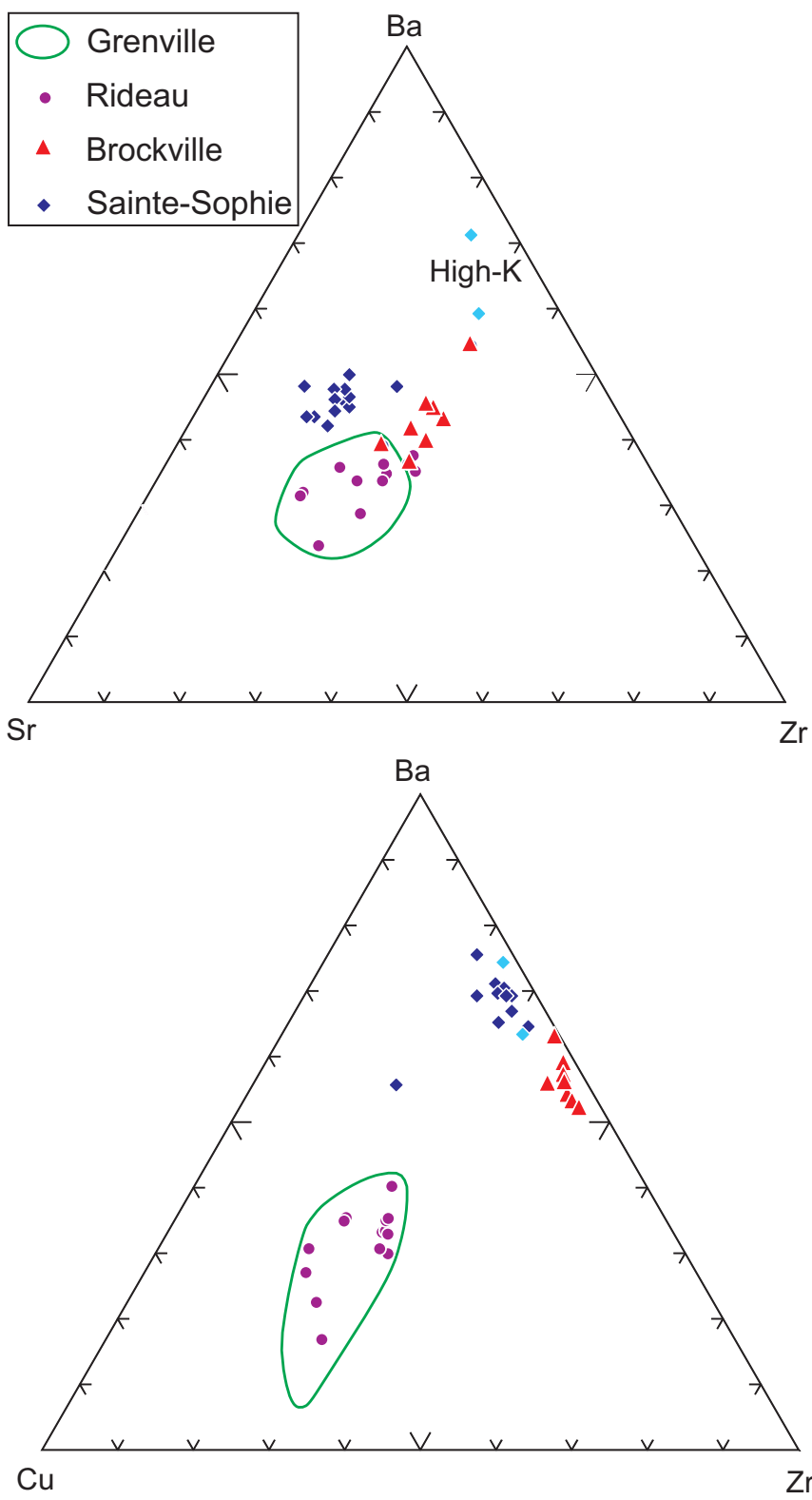

population of crystals, which have not been completely separated from the magma. However, fractionation of plagioclase will not strongly modify the concentration of incompatible elements in the magma.

Davidson et al. (2009) suggested the use of two triangular diagrams to distinguish between different dyke swarms (Fig. 9). The SSD can be better distinguished on these diagrams as compared with simple ("Harker") or ratio diagrams. The greatest difference is seen in the $\mathrm{Cu}$ content: the low content in the SSD and Brockville dykes suggests that sulphides were retained in the mantle during partial fusion, in contrast to the source of the Grenville and Rideau dykes.

Ratios of incompatible elements should be a good discriminant for dykes from different sources, as these ratios are unaffected by fractional crystallization of major mafic phases. With this in mind, Halls et al. (2015) developed a graph of Th/Ta versus $\mathrm{Zr} / \mathrm{Nb}$ 


\section{Pagination not final (cite DOI) / Pagination provisoire (citer le DOI)}

Fig. 10. Th/Ta versus $\mathrm{Zr} / \mathrm{Nb}$ for the Sainte-Sophie dykes (this study) and Grenville dykes (Halls et al. 2015). Samples from the same dyke are linked with a red line. [Colour online.]

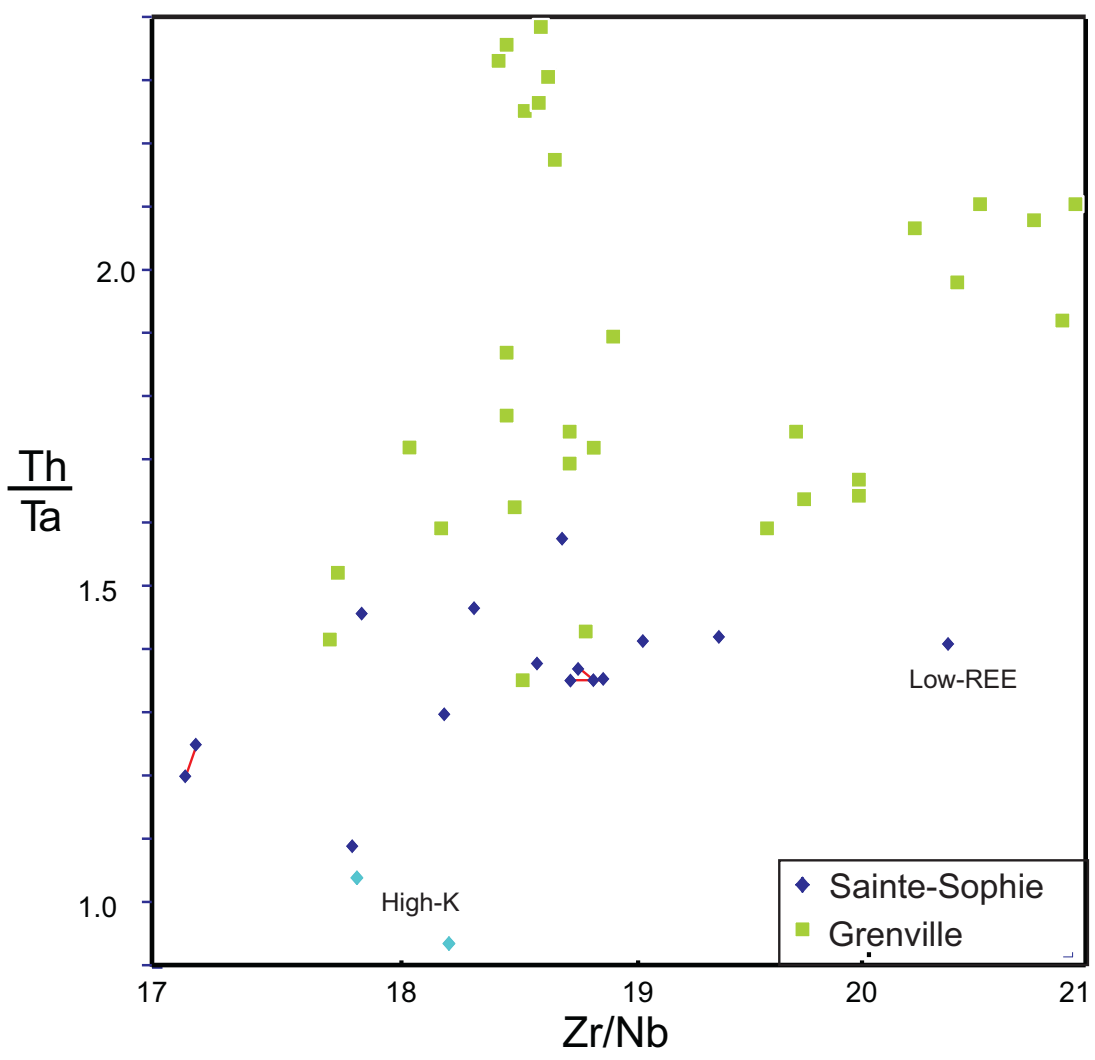

for their study of the Grenville dykes. They concluded that groupings of analyses from individual dykes, or small groups of dykes, indicated different batches of mantle-derived magma. Most of the SSD samples have lower Th/Ta ratios than the Grenville dykes, although there is some minor overlap (Fig. 10). Grouping of the SSD data suggest at least four different mantle sources for the magma, one of which was rich in $\mathrm{K}_{2} \mathrm{O}$.

If diabase dykes are derived from the mantle with only minor fractionation of plagioclase, then their chemical composition should reflect the local composition of the mantle. The SSD are generally more alkaline than the Grenville dyke swarm, and two samples are very K-rich. The nearby alkaline intrusions of the Cretaceous Monteregian province suggest that the underlying mantle in this region was metasomatized. If this event was preEdiacaran, then it could account for the higher alkali content of the SSD. The high-K samples would then reflect a small, highly enriched mantle source.

\subsection{Emplacement and erosion of dykes}

There is abundant evidence that the current level of exposure of the SSD is close to the paleosurface, but it is difficult to place an exact value on the depth. The ubiquitous presence of vesicles in the dykes indicates that they have exsolved a gas phase, which can only occur close to the surface. However, the exact depth will depend on the volatile content and the kinetics of the process. The macroscopically glassy margin of dyke SS-6 also suggests that it was emplaced close to the surface, otherwise slow cooling would have led to more extensive devitrification. The extensive development of zeolites, and other alteration minerals, filling the vesicles and altering the matrix indicates the presence of hydrothermal circulation, which again is most likely close to the surface. The Grenville dykes are consistently nonvesicular and largely unaltered, indicating that they solidified at a much greater depth in the crust.
Fig. 11. A schematic north-south section through the northern margin of the St. Lawrence graben near Sainte-Sophie. We propose that the graben descends in a series of steps, like a staircase, rather than a single fault. The limit between the blocks could also be a ramp. The Sainte-Sophie dykes were emplaced into a block that has had little erosion, as compared with the block that contains the Grenville dykes. Contemporaneous lavas may be still present below the sediments of the St. Lawrence lowlands to the south. [Colour online.]

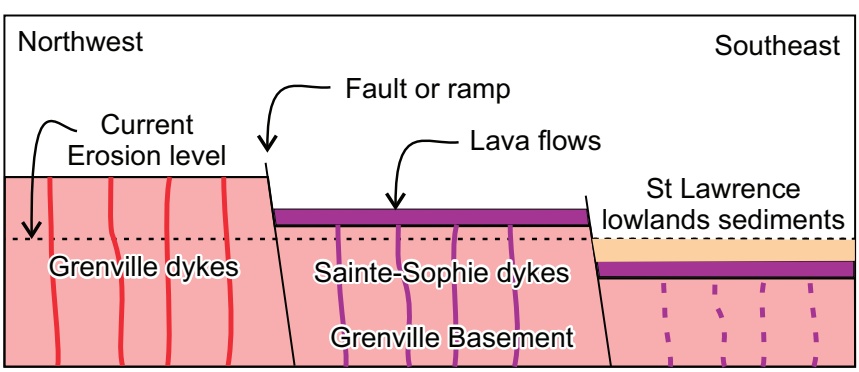

The SSD outcrop close to a major fault of the St. Lawrence rift system. This suggests that the block of the crust containing the SSD was dropped down during rifting with respect to the block to the west, which contains the Grenville dykes, making a "staircase" structure (Fig. 11). We have not located a faulted limit for these blocks, and the structure may be more of a ramp. If this model is correct, then it is possible that lavas are still preserved beneath the St. Lawrence lowlands to the south, and may be found by drilling or a high-resolution aeromagnetic survey. The inferred depth variation between the Grenville dykes and the SSD clearly indicates that this part of the St. Lawrence rift system was tectonically active at this time. 


\section{Pagination not final (cite DOI) / Pagination provisoire (citer le DOI)}

The minor Brockville dykes of southeast Ontario have many similarities with the SSD (Fig. 1; Davidson et al. 2009). These dykes are also relatively narrow with plagioclase macrocrysts and vesicles. They are undated but are paleomagnetically similar to the parallel Rideau dykes that occur in the same region. The Rideau dykes are considered to be synchronous with the Grenville dyke swarm that is further north. The Brockville dykes may also indicate the presence of another basement block that has not been significantly eroded, in a similar tectonic position to the SSD block. However, the Brockville dykes must be dated before this idea can be developed.

\section{Conclusions}

1. The SSD were emplaced at $591.6 \pm 2.5 \mathrm{Ma}$, which is synchronous with the extensive Grenville Dyke swarm to the west.

2. The SSD are a distinct facies of the large Grenville dyke swarm. They have the same orientation and age as the Grenville dykes, but differ in their composition and level of emplacement.

3. The SSD, like many other dyke swarms, were the product of many small magmatic events. Each event comprised melting in the mantle, transport and storage at mid-crustal levels, and finally transport to the subsurface.

4. The SSD were fed from a mantle source that was distinct from that of the rest of the Grenville dykes. This may also have been the source of the Cretaceous Monteregian intrusions.

5. The basement block hosting the dykes has seen little erosion since $\sim 592 \mathrm{Ma}$, probably because this block has been dropped down by the same process that created the St. Lawrence rift to the southeast. Contemporaneous lavas may be still preserved beneath the St. Lawrence lowland sediments to the south. The St. Lawrence rift system must have been tectonically active here at $\sim 592 \mathrm{Ma}$.

\section{Acknowledgements}

This research was supported by a Natural Sciences and Engineering Research Council of Canada (NSERC) Discovery grant to M.D.H. We would like to thank Charles Verdel for help in the field.

\section{References}

Buchan, K.L., and Ernst, R.E. 2004. Diabase dyke swarms and related units in Canada and adjacent regions. "A" Series Map 2022A. Geological Survey of Canada, Ottawa, Canada.

Buchan, K., and Hamilton, M. 2009. New geochronologic and paleomagnetic results for the Grenville Dyke Swarm and implications for the Ediacaran APWP for Laurentia. In EOS, Transactions of the American Geophysical Union. Vol. 90, No. 22.

Buchan, K., Hamilton, M., Davidson, A., and Ernst, R. 2011. U-Pb geochronology and magnetic overprinting of late Neoproterozoic dyke swarms associated with Ottawa Bonnechere and Timiskaming grabens and SW faults of the upper St. Lawrence River. In Geological Association of Canada Annual Meeting. p. 29.

Davidson, A., Hamilton, M.A., Heaman, L.M., Ernst, R.E., and Buchan, K.L. 2009. Grenville diabase dyke swarm; extent, age and comparative geochemistry. In EOS, Transactions of the American Geophysical Union. Vol. 90, Suppl. 22.

Doig, R., and Barton, J.M., Jr. 1968. Ages of carbonatites and other alkaline rocks in Quebec. Canadian Journal of Earth Sciences, 5: 1401-1407. doi:10.1139/e68-139.

Ernst, R.E. 2014. Large igneous provinces. Cambridge University Press, Cambridge, UK.

Ernst, R.E., and Buchan, K.L. 2010. Geochemical database of Proterozoic intraplate mafic magmatism in Canada. Open File 6016. Geological Survey of Canada, Ottawa, Canada.

Halls, H.C., Lovette, A., Hamilton, M., and Soderlund, U. 2015. A paleomagnetic and $\mathrm{U}-\mathrm{Pb}$ geochronology study of the western end of the Grenville dyke swarm: Rapid changes in paleomagnetic field direction at ca. 585 Ma related to polarity reversals? Precambrian Research, 257: 137-166. doi:10.1016/j. precamres.2014.11.029.

Higgins, M.D., and van Breemen, O. 1998. The age of the Sept Iles layered mafic intrusion, Canada: Implications for the late Neoproterozoic/Cambrian history of southeastern Canada. Journal of Geology, 106(4): 421-432. doi:10.1086| 516033.

Kamo, S.L., Krogh, T.E., and Kumarapeli, P.S. 1995. Age of the Grenville Dyke Swarm, Ontario-Quebec: Implications for the timing of Iapetan rifting. Canadian Journal of Earth Sciences, 32(3): 273-280. doi:10.1139/e95-022.

Kumarapeli, P.S., and Saull, V.A. 1966. The St. Lawrence Valley system: a North American equivalent of the east African rift valley system. Canadian Journal of Earth Sciences, 3: 639-657. doi:10.1139/e66-045.

Lee, J.-Y., Marti, K., Severinghaus, J.P., Kawamura, K., Yoo, H.-S., Lee, J.B., and Kim, J.S. 2006. A redetermination of the isotopic abundances of atmospheric Ar. Geochimica et Cosmochimica Acta, 70(17): 4507-4512. doi:10.1016/j.gca. 2006.06.1563.

McCausland, P.J.A., Van der Voo, R., and Hall, C.M. 2007. Circum-Iapetus paleogeography of the Precambrian-Cambrian transition with a new paleomagnetic constraint from Laurentia. Precambrian Research, 156(3-4): 125-152. doi:10.1016/j.precamres.2007.03.004.

McDougall, I., and Harrison, T.M. 1999. Geochronology and thermochronology by the ${ }^{40} \mathrm{Ar} /{ }^{39} \mathrm{Ar}$ method. Oxford University Press, New York.

Osborne, F.F., and Clark, T.H. 1960. New Glasgow - St-Lin area, electoral district of Montcalm, Terrebonne and l'assomption. RG 91. Quebec Department of Mines, Quebec City.

Renne, P.R., Mundil, R., Balco, G., Min, K., and Ludwig, K.R. 2010. Joint determination of ${ }^{40} \mathrm{~K}$ decay constants and ${ }^{40} \mathrm{Ar} *{ }^{40} \mathrm{~K}$ for the Fish Canyon sanidine standard, and improved accuracy for ${ }^{40} \mathrm{Ar} /{ }^{39} \mathrm{Ar}$ geochronology. Geochimica et Cosmochimica Acta, 74(18): 5349-5367. doi:10.1016/j.gca.2010.06.017.

Seymour, K.S., and Kumarapeli, P.S. 1995. Geochemistry of the Grenville dyke swarm: Role of plume-source mantle in magma genesis. Contributions to Mineralogy and Petrology, 120(1): 29-41. doi:10.1007/Bf00311006.

Steiger, R.H., and Jäger, E. 1977. Subcommission on geochronology: Convention on the use of decay constants in geo- and cosmochronology. Earth and Planetary Science Letters, 36: 359-362. doi:10.1016/0012-821X(77)90060-7.

Sun, S.S., and McDonough, W.F. 1989. Chemical and isotopic systematics of oceanic basalts: implications for mantle composition and processes. In Magmatism in the ocean basins. Edited by A.D. Saunders and M.J. Norry. Geological Society of London, Special Publication 42, pp. 313-345.

Verati, C., and Jourdan, F. 2014. Modelling effect of sericitization of plagioclase on the ${ }^{40} \mathrm{~K} /{ }^{40} \mathrm{Ar}$ and ${ }^{40} \mathrm{Ar} /{ }^{39} \mathrm{Ar}$ chronometers: implication for dating basaltic rocks and mineral deposits. Geological Society of London, Special Publication 378, pp. 155-174. doi:10.1144/SP378.14. 